\author{
Vira SLIPETSKA, \\ orcid.org/0000-0002-2569-0197 \\ Candidate of Philological Sciences, Associate Professor, \\ Associate Professor at the Department of Germanic Languages and Translation Studies \\ Educational and Scientific Institute of Foreign Languages \\ of Drohobych Ivan Franko State Pedagogical University \\ (Drohobych, Lviv region, Ukraine) vslipetska@ukr.net
}

\title{
OUTLINING THE ISSUES OF LINGUISTICS OF EMOTIONS IN THE SYSTEM OF VIEWS OF CHARLES BALLY AND LEV BULAKHOVSKY
}

The article focuses on analyzing the issues of linguistics of emotions in the system of views of Charles Bally and Lev Bulakhovsky. Linguistics of emotions is a new direction in linguistics. It has its history and formation stages. Linguistics of emotions is formed on the margin of different sciences: linguo-philosophy, taking into account semantics, pragmatics, psycholinguistics, linguo-culturology, linguo-conceptology, ethno-linguistics, gender linguistics, etc. The goal of the article is to outline the issues of linguistics of emotions in the system of views of Charles Bally and Lev Bulakhovsky.

Charles Bally emphasized that the most important are the emotional and affective components of speech. He elaborated the system of stylistic parameters to describe speech, taking into account the impact of emotions and feelings on the language. He considered the expression of "subjectivity" in the language as the widest possible range of means of reflecting the personality and emotions of the speaker. His main contribution to the theory of language is considered to be the concept of modality.

Lev Bulakhovsky was convinced that our emotions and feelings are verbalized and grammaticalized. The researcher considered an obligatory emotional component in the structure of the language personality. According to Lev Bulakhovsky the theory of fiction language is valuable, in particular, because, in contrast to the usual intellectual guidelines of semantics, it focuses far more on an emotional aspect of the language.

The scholar also focused on the formation of an emotional vocabulary system. The researcher also notes that emotions are clearly verbalized in polemical texts of the Ukrainian authors. A separate research of the scientist is directly devoted to psycho-linguistics, which he called the psychology of the language. According to Lev Bulakhovsky, great emotionality is contained in the paremic units. Focusing on the trends in the development of literary languages, Lev Bulakhovsky believes that the language offers a number of tools for the representation of emotionality and affectivity.

Key words: linguistics of emotions, system of views, Charles Bally, Lev Bulakhovsky, emotional and affective components, speech, emotional vocabulary system, emotionality and affectivity.

Віра СЛІПЕЦЬКА, orcid.org/0000-0002-2569-0197 кандидат філологічних наук, доцент, доиент кафедри германських мов і перекладознавства Навчально-наукового інституту іноземних мов Дрогобиџького державного педагогічного університету імені Івана Франка (Дрогобич, Львівська область, Украӥна) vslipetska@ukr.net

\section{ОКРЕСЛЕННЯ ПРОБЛЕМАТИКИ ЛІНГВІСТИКИ ЕМОЦЙ У СИСТЕМІ ПОГЛЯДІВ ШАРЛЯ БАЛЛІ ТА ЛЕВА БУЛАХОВСЬКОГО}

\footnotetext{
Статтю присвячено аналізу проблематики лінгвістики емоцій у системі поглядів Шарля Баллі та Лева Булаховського. Лінгвістика емочій як напрям мовознавства скерована на розуміння світу емоцій крізь мову не просто як накопичення явищ і фактів, а як осмислення ицих фактів і явищ у сукупності - як иілісність. Шарль Баллі як і деякі інші представники Женевської школи, вважав, шуо мовлення відображає всі аспекти життя. Думки, що в ньому відображаються, мають не лише інтелектуальну природу, вони включають і спонукання до діï, емоції, бажання і волю.

Шарль Баллі наголошував, щчо найбільш важливими є емоційно-афективні компоненти мовлення - форми, щзо зникають і змінюються через множсиність смислових відтінків. Його дослідження в ціій галузі нині стали загальноприйнятими, однак не відразу знайшли розуміння в сучасному йому науковому світі: мовознавиям здавалося, щзо аналіз явищ, які не підлягають суворій регламентації, суперечать логіиі наукового мислення. Шарль Баллі вклав новий зміст у термін «стилістика», відділивии лінгвістичну стилістику від традиційних досліджень літературно-художніх стилів. Вчений почав розробляти систему стилістичних параметрів для опису мовлення з урахуванням впливу на мову емочій та почуттів.
} 
Лев Булаховський був переконаний, щзо наші емоиії і почуття вербалізуються і граматикалізуються, своєрідно виражаючись на усіх мовних рівнях, щуо найбільш виразно можна простежити в мові художньої літератури. На думку Лева Булаховського, велику емоційність містять паремійні одиниці. Дослідник вважав обов'язковим емоційний компонент у структурі мовної особистості.

Вчений звернув увагу на формування системи емочійної лексики. Дослідник підмітив й те, щзо емоції виразно вербалізуються в полемічних текстах українських авторів. Окрема розвідка вченого безпосередньо присвячена психолінгвістиці, яку він називав психологією мови. На думку науковия, мова пропонує низку інструментів для відображення емоційності та афективності.

Ключові слова: лінгвістика емоцій, система поглядів, Шарль Баллі, Лев Булаховський, емоиійно-афективні компоненти мовлення, система емоційної лексики, емоційність та ефективність.

Introduction. Linguistics of emotions is a new direction in linguistics and it is formed on the margin of different sciences: linguo-philosophy, taking into consideration semantics, pragmatics, psycholinguistics, linguo-culturology, linguo-conceptology, ethnolinguistics, gender linguistics, etc. Linguistics of emotions integrates the knowledge of a number of linguistic tendencies into a coherent system.

Emotions were the subject of the research by Charles Darwin, who elaborated the biological concept of emotions, according to which typical "emotional movements" were interpreted by him as a rudiment of important instinctive manifestations (Slipetska, 2017). In the middle of the XIXth century, the most promising was the psychology of nations (in German - "Völkerpsychologie"), elaborated by W. Wundt. The issue of linguistics emotion was raised in the works of O. Potebnia (1835-1891), first of all in his key monograph "Thought and Language" (Slipetska, 2017).

The goal of the article is to outline the issues of linguistics of emotions in the system of views of Charles Bally and Lev Bulakhovsky.

The goal of the research requires the fulfillment the following objectives:

a) to elucidate the system of views on emotions by Charles Bally;

b) to highlight the system of views on emotions by Lev Bulakhovsky.

Presentation of the Results. At the end of the XIXth - the first half of the XXth century Charles Bally (1865-1947), who belonged to the first generation of the Geneva School of Sociology in Linguistics, did his scientific researches. Ch. Bally, like some other members of the Geneva school, believed that speech reflects all aspects of life. The thoughts reflected in speech are not only intellectual in nature, they include the urge to act, emotions, desires and will.

Ch. Bally emphasized that the most important are the emotional and affective components of speech the forms, which that disappear and change due to the multiplicity of shades of meaning (Bally, 1955). Nowadays, his research in this area has become commonplace, but it was not immediately understood in Ch. Bally's scientific world: linguists thought that the analysis of phenomena that are not the subject to a strict regulation, are contrary to the logic of scientific thinking. Ch. Bally added a new meaning to the term "Stylistics", singling out linguistic stylistics, which he defined as "the science of means of expression" (Bally, 1955). It was Ch. Bally, who began to elaborate the system of stylistic parameters to describe speech, taking into account the impact of emotions and feelings on the language.

Thus, we should emphasize that according to Ch. Bally linguistic stylistics studies the whole language from the point of view of affectivity, because, as he noted, the ways of expressing the affective can be phonetic, lexical and grammatical. However, according to Ch. Bally stylistics does not give preference to the affective over the intellectual, it studies them in interaction, as well as in the proportions, in which they are mixed to give rise to a particular type of a linguistic expression.

Ch. Bally's main theme was the study of the expression of "subjectivity" in the language, which he understood as the widest possible range of means of reflecting the personality and emotions of the speaker. These aspects motivated his interest in stylistics, which the scientist considered an independent linguistic discipline. The most important work of Ch. Bally is "General and French Linguistics" (in French - Linguistique générale et linguistique française, 1932), in which the ideas about the nature of variability and evolution of the language, morphology and syntax, the specifics of the grammatical structure of the French language, etc., are represented.

However, his main contribution to the theory of language is considered to be the concept of modality and communicative organization of the sentence. This theory is also partly based on the theoretical foundations of psycholinguistics, as it actualizes the problem of the connection of emotions and feelings with the categories of modality and evaluation, because the scientist professed emotivism, based on the actualization of emotions and feelings as motives for behaviour, which is consistently reflected in speech as a type of a human activity. 
The scientist actualized the theory of a sensory cognition, considering it as a conditional level of a cognitive activity, which is singled out in the theoretical analysis to understand the input components of knowledge. A human cognition is impossible without fixation nerve signals. A sensory cognition is an opening of the world to a person: it gives the human intellect the initial impulses to develop its activity, it orients a person in reality and promotes the formation in his mind of certain images consisting of sensory data and connections between them.

L. Bulakhovsky (1888-1961), O. Potebnia's student, consistently implemented O. Potebnia's conceptual principles, developing them, which primarily concerns psycholinguistics and linguistics of emotions. However, the scientist accepted the postulates of his predecessors especially W. Wundt and Ch. Bally.

L. Bulakhovsky was convinced that our emotions and feelings are verbalized and grammaticalized, uniquely expressed at all language levels, which can be most clearly traced in the language of fiction, in particular, actualizing the conception of W. Wundt on collective psychology, L. Bulakhovsky wrote, that "the theory of fiction language is valuable, in particular, because, in contrast to the usual intellectual guidelines of semantics, it focuses far more on an emotional aspect of the language, it takes into account the fact that the emotional elements, various feelings permeate the language and therefore, it can be correctly imagined only inseparably from them.

When we speak, we not only express our thoughts and narrations, but also express the feelings by means of words, which accompany our thoughts and ideas in one way or another. Our "I/Ego" is repeatedly reflected in our speech, and we as personalities and bearers of the psychology of certain groups are actually deprived of the ability to speak so, that our attitude to the objective content of what is said does not hide in itself the moments of evaluation, the statement of various pleasant or unpleasant feelings associated with them, and the signs of our willingness to react in one way or another.

The means of expression for us are the selection of synonymous words and forms, and special peculiarities of morphology and word order, and psychological peculiarities of individual sounds, and an infinite variety of shades of timbre, when they go beyond the most typical qualitative differences of the sounds of a particular language, and the whole rhythmic and melodic side of speech with its variations in strength, tone, longitude, pauses" (Bulakhovsky, 1975, V. 1). As we can see, being ahead of time, L. Bulakhovsky considered an obligatory emotional component in the structure of the language personality. In addition, L. Bulakhovsky proved that "the role of a powerful expression of the feelings of the people in their native language belonged to Taras Hryhorovych Shevchenko (1814-1861).

It is owing to Taras Shevchenko that the Ukrainian language in writing acquires a literary significance, gains recognition and respect, especially among the people, who gave birth to the language and nurtured it, as well as among other Slavic peoples, in which his poetry finds a response to its subject matter, images, the range of emotions inherent in it and the skill of expression" (Bulakhovsky, 1975, V. 1). L. Bulakhovsky notes that it was T. Shevchenko, who set in motion "the richness of emotional means (from expressions of a fiery anger to the most tender kindness) of the language of the broad masses of the peasantry of the Dnieper region; a solemn and partly emotionally sensible element and vivid phraseology of Church Slavonic in their distinctly artistic orientation and all that from the current language of the Ukrainian village, which could not be avoided by poetry, which arose in the soul of the observant and with all sympathies associated with the common people of a poet-serf" (Bulakhovsky, 1975, V. 2).

The scholar also focused on the formation of a system of emotional vocabulary, noting that "the history of emotional vocabulary is characterized by the scope gained by writers using abusive words and their selection, which in view of modern rules of a literary ethics sometimes seems rude and vulgar" (Bulakhovsky, 1975, V. 1). The scholar's attention is focused on the manifestation of negative emotions, which is represented by the use of abusive vocabulary, appropriate interjections, the theory of which was developed by O. Potebnya. L. Bulakhovsky studied this aspect taking into consideration the data of other languages, in particular, Polish.

In a special research, L. Bulakhovsky analyzed emotional vocabulary, reflecting on the path of its entry into a literary speech. He believes that "against the replenishment of the literary dictionary with signs of new concepts, important is the penetration into it a specifically emotional vocabulary, too low, that for some time lives only as inherent in the lower social strata of the society. In a literary language, at first it penetrates as a genre, as the language of fiction characters, causing, whether the narrator wants it or not, a more or less contemptuous or condescending attitude to the depicted "lower social strata of the society". During political and social changes, it, this affective vocabulary of the lower circles of the society, wins the rights as a real layer of permitted ways of speech in a literary use and satisfies, among 
other things, the needs of the language not so much in enriching its content as in increasing a stylistic flexibility" (Bulakhovsky, 1975, V. 1). In this case, L. Bulakhovsky develops the ideas of Charles Bally.

The researcher also noted that emotions are clearly verbalized in polemical texts of the Ukrainian authors, noting that "I. Vyshensky, all his constricted temperament, compressed by the conditions of a monk, poured out in those places of his polemical works, which by their subject matter directed him to the sources of the life familiar to him, to the expression of the angry feelings of the masses, with its vivid phraseology" (Bulakhovsky, 1975, V. 1).

A separate research of the scientist is directly devoted to psycho-linguistics, which he called the psychology of the language. The researcher emphasized that psycho-linguistics did not have an outlined object and subject, objectives, methodology at that time, i.e., the science was just being formed, although there were many researches, cf.: "Psychology of the language is a large area of linguistic studies without the exact content of its object and without clearly defined boundaries. Psychology of the language usually includes a range of different issues, more or less related to the fact that they are all "psychological", i.e., reflect their belonging to the inner world of a human being and get the explanation of the phenomena and factors, according to which this complex and capricious, very active device operates. The psychology of nations (in German: Völkerpsychologie), widely elaborated developed by W. Wundt, is considered to be particularly promising" (Bulakhovsky, 1975, V. 1). L. Bulakhovsky described in detail the conception of W. Wundt, highlighting the key provisions.

The scientist criticized the views of D. OvsyanykoKulykovsky, emphasizing that the philosophical basis of "psychologism" according to D. OvsyanykoKulykovsky is ruled by a subjective idealism, which he eclectically combined with Ch. Darwin's theory of evolution and the little-known conception of the French philosopher I. Ten on the impact on the individual environment" (Bulakhovsky, 1975, V. 1).

Reflecting on the interaction of Psychology and Linguistics, the researcher believed that "linguistics does not do without psychology, and when it does..., then with a clear one-sided approach to the case, with a distortion of the general perspective and impoverishment of possible conclusions. ... Psychology takes more from linguistics than it gives" (Bulakhovsky, 1975, V. 1).

The researcher also focuses on the realization problem of speech affectivity, rightly noting that "from time to time it is necessary to take into account the difference in this respect between groups of speakers depending on gender, age, profession, education, living and communication conditions, etc." (Bulakhovsky, 1975, V. 1). The scholar emphasizes that intellectuals "use the types of speech that are less affective than illiterate people and groups of a relatively low level of culture. Although individual characters also play a significant role, the leading factor here is the social moment - the appropriate stratification of the society and, depending on this stratification and the degree of affectivity of speech and its distribution among the groups of population" (Bulakhovsky, 1975, V. 1).

According to L. Bulakhovsky, great emotionality is contained in the paremic units, which are used by ordinary people in their speech: they have a habit "to mix their speech with affectively colored words from national dialects or from slang of various groups of the population" (Bulakhovsky, 1975, V. 1). Reflecting on women's speech, the scientist points at a high level of emotionality of women's speech compared to men's speech. This point of view became the main one in the theory of gender linguistics nowadays.

Focusing on the trends in the development of literary languages, L. Bulakhovsky believes that the language offers a number of tools for the representation of emotionality and affectivity, cf.: "Literary languages in their development generally go through the development of means of ornamentality periphrasticity and figurativeness, i.e., the ways to retell thoughts by means of tropes, indirectly, thus spreading associative - cognitive capabilities of words and phrases, and arrange the words not in the usual established order, but in new relative to their place combinations of syntagms, in a modified, inverted order, able to take on special functions - emotional, affective and, to a lesser extent, intellectual (logical)" (Bulakhovsky, 1975, V. 1).

The Conclusions. Thus, Charles Bally believed that speech reflects all aspects of life. The thoughts reflected in speech are not only intellectual in nature, they include the urge to act, emotions, desires and will. Charles Bally emphasized that the most important are the emotional and affective components of speech. It was Charles Bally, who began to elaborate the system of stylistic parameters to describe speech, taking into account the impact of emotions and feelings on the language.

According to Charles Bally linguistic stylistics studies the whole language from the point of view of affectivity. However, stylistics does not give preference to the affective over the intellectual, it studies them in interaction. Charles Bally understood "subjectivity" in the language as the widest possible 
range of means of reflecting the personality and emotions of the speaker. The scientist professed emotivism based on the actualization of emotions and feelings as motives for behavior. Charles Bally actualized the theory of a sensory cognition

Thus, Lev Bulakhovsky systematically reflected on the emotional aspect of the language, using the appropriate terminology ("emotional language means", "emotionally sensible language element", "specifically emotional vocabulary", "affective way of speaking", "emotional side of speech", "emotional vocabulary", "affective vocabulary", "affectively colored words", "emotional function of language", "affective function of language"), distinguishing between emotionality and affectivity, indicating the ways of their implementation in speech, its various genres and styles; he analyzed the problem of the history of the emergence of emotional vocabulary and its penetration into a literary speech, its functions for the implementation of the principles of flexibility, imagery, aesthetics; the researcher analyzed the latest psycho-linguistic theories, leaving appropriate comments on the social aspects of the expression of emotionality or sensuality.

\section{BIBLIOGRAPHY}

1. Балли Ш. Общая лингвистика и вопросы французского языка. Москва : Изд-во иностранной литературы, $1955.416 \mathrm{c}$.

2. Булаховський Л. А. Вибрані праці в п’яти томах. Загальне мовознавство: Теорія художньої мови. Т. 1. Київ : Наук. думка, 1975. С. 85.

3. Булаховський Л. А. Вибрані праці в п’яти томах. Розвиток української літературної мови. Т. 2. К. : Наук. думка, 1977. C. 235.

4. Сліпецька В. Д. Лінгвістика емоцій: формування і розвиток (історико-теоретичний опис; бібліографічний покажчик). Дрогобич : Редакційно-видавничий відділ ДдПУ імені Івана Франка, 2017. 354 с.

\section{REFERENCES}

1. Bally Ch. Obshchaya lingvistika i voprosy frantsuzskogo yazika. Moskva : Izd-vo inostrannoy literatury [General Linguistics and Questions of the French Language]. M. : Publishing house of foreign literature, 1955. 416 p. [in Russian].

2. Bulakhovsky L. A. Vybrani pratsi v pryaty tomakh. Zahal'ne movoznavstvo: Teoriya khudozhn'oyi movy [Selected Works in Five Volumes. General Linguistics: Theory of Artistic Language]. V. 1. K. : Nauk. Dumka, 1975. P. 85 [in Ukrainian].

3. Bulakhovsky L. A. Vybrani pratsi v pryaty tomakh. Rozvytok ukrayins'koyi literaturnoyi movy [Selected Works in Five Volumes. Development of the Ukrainian Literary Language]. V. 2. K. : Nauk. Dumka, 1977. P. 235 [in Ukrainian].

4. Slipetska V. D. Linhvistyka emotsiy: formuvannya i rozvytok (istoryko-teoretychnyy opys; bibliohrafichnyy pokazhchyk) [Linguistics of Emotions: Formation and Development (Historical and Theoretical Description; Bibliographic Index)]. Drohobych : Editorial and Publishing Department of Ivan Franko State Pedagogical University, 2017. 354 p. 